\title{
Annual Assessment of Al-Furat Al-Awsat Technical University ATU Sustainability Development Goals for GreenMetric World University Rankings
}

\author{
Mudhaffar S. Al-Zuhair ${ }^{1,}$, Essam O. Al-Zaini ${ }^{2}$, Ahmed Ghanim Wadday ${ }^{3}$ \\ ${ }^{1}$ Chencellor, Al-Furat Al-Awsat Technical University ATU, Kufa Campus, Kufa City, Republic of Iraq \\ ${ }^{2}$ Chencellor, Al-Furat Al-Awsat Technical University ATU, Kufa Campus, Kufa City, Republic of Iraq \\ ${ }^{3}$ Vis Chancellor for scientific Affair, Al-Furat Al-Awsat Technical University ATU, Kufa Campus, Kufa City, \\ Republic of Iraq \\ *corresponding author: mudhaffar@atu.edu.iq
}

\section{Article Info}

\section{Received:}

15 March 2021

Accepted:

25 May 2021

Published:

1 June 2021

DOI:

https://doi.org/10.14710/j

sp.2021.11200

\begin{abstract}
Al-Furat Al-Awsat Technical university ATU, is one of the newly established academic institutions in Republic of Iraq. Since its emergence in 2014, presently the university is keen to secure its position among other internationally to be a well recognized academic institutions, thereby addressing all sustainable goals and related challenges in its futuristic development schemes. These include developing all existing educational programs and schemes, developing in campus faculty infrastructures, implementing alternative energy resources, developing waste managements, enhancing potable water conservation existing projects and evolving existing transportation structures. This current manuscript highlights in depth all the above indicated developments schemes thereby examining their implementation stages and addressing all associated challenges that face the university. It also looks at its potentials and capabilities to overcome such issues.
\end{abstract}

\section{Keyword:}

ATU, infrastructure, sustainable goals, renewable energy, rankings \& education

\section{Introduction}

Increasing global concerns on environmental issues and in particular climatic change, has driven academic institutions to promote environmental concerns to the society through creating knowledge and integrating sustainability in their educational and research programs. This resulted in the initiation of what commonly known green universities [1]. In 
this respect, it has been reported that training plays an important role during the implementation of environmental management system (EMS) within a university campus [2]. Within a Mexican university campus, a solid waste management system integration was examined by Espinosa, R.M., et al., 2008 [3]. It has been reported that students' environmental awareness can be significantly improved through the implementing zero waste program within the university campus [4]. In another study, the author reported that ongoing education and training is a key factor in order to achieve high standard of source separation of resource residuals from both the kitchen/cafeteria staff and the university community [5].

Climatic change on the other hand has gained remarkable researchers' attention. In this respect, and aiming to prepare an appropriate emission reduction policy, carbon footprint was investigated by researchers at Norwegian University of Science and Technology (NTNU) [6]. They applied an Environmental Extended Input Output (EEIO) model and identified key emission source in the university campus. Establishing green universities practices were reviewed [7]. The study included many aspects including indicators, criteria, best practices and relevant policies. Different indicator systems established for assessing the overall performance of single green university project were reviewed Wang. L., 2011 [8]. Development of a low carbon campus scheme, including some carbon emission reduction strategies and capacity buildings efforts was proposed [9].

Since its emergence in 2014, Al-Furat Al-Awsat Technical University ATU adopted a direct role in addressing the sustainable development goals SDGs and in particular those highlighted by the green metrics world universities rankings. This is due to the fact that implementing SDGs will greatly help ATU to demonstrate its impact as a responsible and globally aware academic institution [10]. However, ATU contribution to the SDGs appears to be much broader, through the supporting the SDG operations and implementing each SDG framework itself, thereby covering multi areas such as; infrastructure, energy and climate change, waste and water managements, transportation and education [11]. Like almost all other academic institutions, ATU provides people with professional and personal skills and capabilities. ATU has access to a remarkable number of young and curious people who are passionate, creative and have a desire for a better world. ATU therefore needs to ensure equipping current and future leaders, decision-makers, teachers and innovators with the knowledge, skills and motivation towards achieving the previously indicated SDGs.

Indeed, a large amount of water flow and energy consumption exist during the operation of one university through both direct (the use of classrooms, laboratories, offices and catering) activities by students and employees. These activities bring significant environmental impacts due to the complexity and diversity of their operations. Typical issues include and not limited to energy and portable water consumptions and air pollution. Therefore, it is important to identify more sustainable options for reducing their environmental footprints. Current manuscript maps what had been done by ATU so far to implement three important SDGs including infrastructure, energy and climate change, and education. The study identifies priorities, Integrating, implementing and embedding such SDGs within the university strategies, policies and futuristic plans.

\section{Infrastructure}

Providing capacity buildings to facilitate the university tasks is crucial since its part of the institutional infrastructure. This includes classrooms, auditorium, laboratories, computer facilities, library facilities, cafeterias, residential accommodations, sport stadiums, car parking, green areas and medical facilities. In this respect, ATU is committed to significant 
enhancement of its facilities and buildings, essential for world-class research and all-round development of students. However, ATU realized that shifting towards green campuses should be in extreme priority in all its development schemes. Considering university infrastructure, ATU has made great efforts towards integrating green campuses aspects in its infrastructure development projects. In this respect, the university emphasized some vital steps to be considered in the renovation of the existed buildings and the implementations of new one projects. Highlighted points include; installing improved insulation systems, modified ventilation systems, energy efficient lighting systems, energy rated appliances, water saving systems, security systems including cameras and alarms, smart door locks, emergency exit signs and maps as well as auto-actuated sprinkle systems and fire alarms. Fig. 1, below displays the percentage of progress in the implementation of the above indicated features.

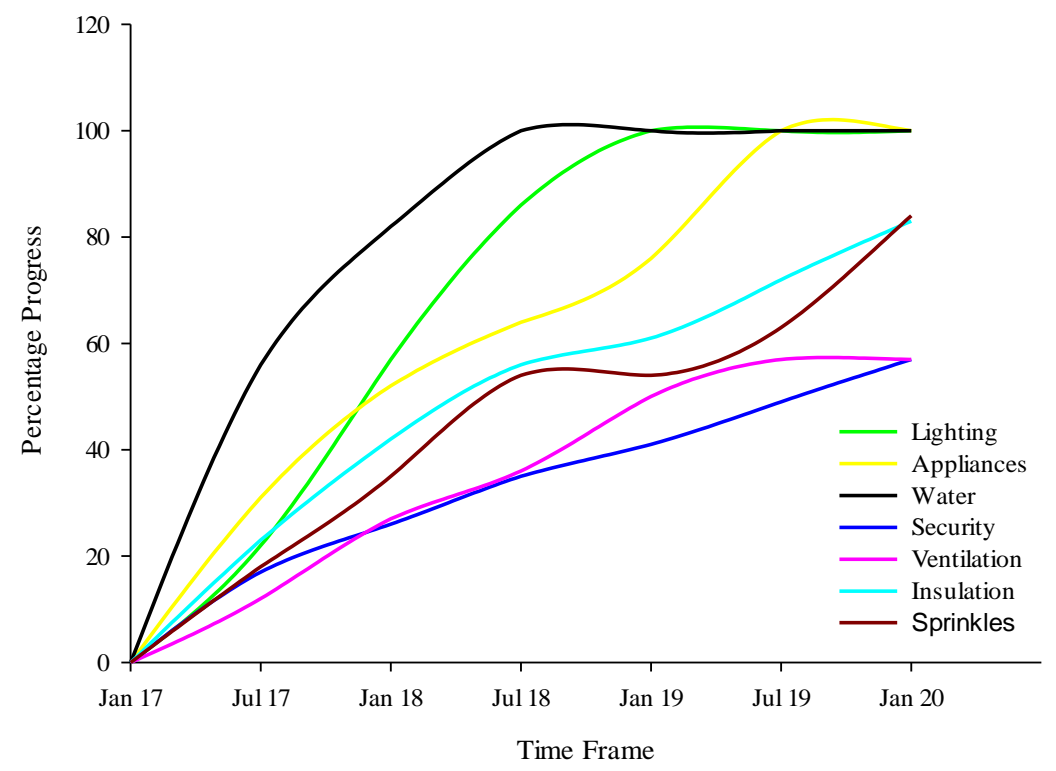

Figure 1. Progress of ATU sustainable development projects in three years' time frame

Considering the figure above, it would seem that ATU is remarkably progressing towards green campuses in many projects such as the installation of energy saving lighting systems, water conservations and energy rated appliances. However, other projects are yet incomplete due to many reasons. Lack of funds would be the dominant reason since ATU is rapidly expanding thereby establishing new buildings, facilities, scientific departments as well as in campus roads and parks. Such developments consumes about $32 \%$ of the university annual income budget. The rest of the fund is used for normal university ongoing activities including teaching and researches. Consequently, some projects should be postponed to the next academic year as the required fund becomes available. On the other hand, since Al-Furat Al-Awsat Technical university ATU has been emerged from the Foundation of Technical Education, founded in 1969, it has many buildings and facilities which are more three decades old. Renovating such constructions to smart buildings standards becomes time and cost consuming practice, which tends to negatively affect the progress of some development projects as shown in figure (1) above.

\section{Energy and Climate Change}

ATU is confident that on-campus solar energy systems help its colleges and intuitions to shift to 100 percent clean and renewable energy. It also believes that such practice help to save funds, provide learning opportunities for students, and achieve its ultimate goals 
towards the green campuses. Solar energy is pollution-free, virtually inexhaustible, safe and efficient, solar energy is a clean and renewable alternative to fossil fuels. Solar energy is so abundant that developing country such as Iraq could generate about 100 times as much electricity from solar power installations as the nation currently consumes each year. Solar energy is a key to helping our society shift away from today's energy system built on polluting fossil fuels.

In this respect, and as a vital part of its development scheme ATU have Installed solar arrays in open spaces like building's rooftops that are perfect for solar energy projects. Nowadays, about $11 \%$ of the overall electricity usage is solar generated one at the ATU main Kufa campus buildings, and the percentage is less in other university campuses. In spite of such value, ATU is looking forward to further expand the project thereby using parking lots, open fields and on parking lot canopies and shade structures in campus for solar panels installation, reaching its optimal goal of $100 \%$ reliance on solar energy by 2030 . Fig. 2 below illustrates the progress of solar panels installations versus overall fossil-based electricity usage in the university sites.

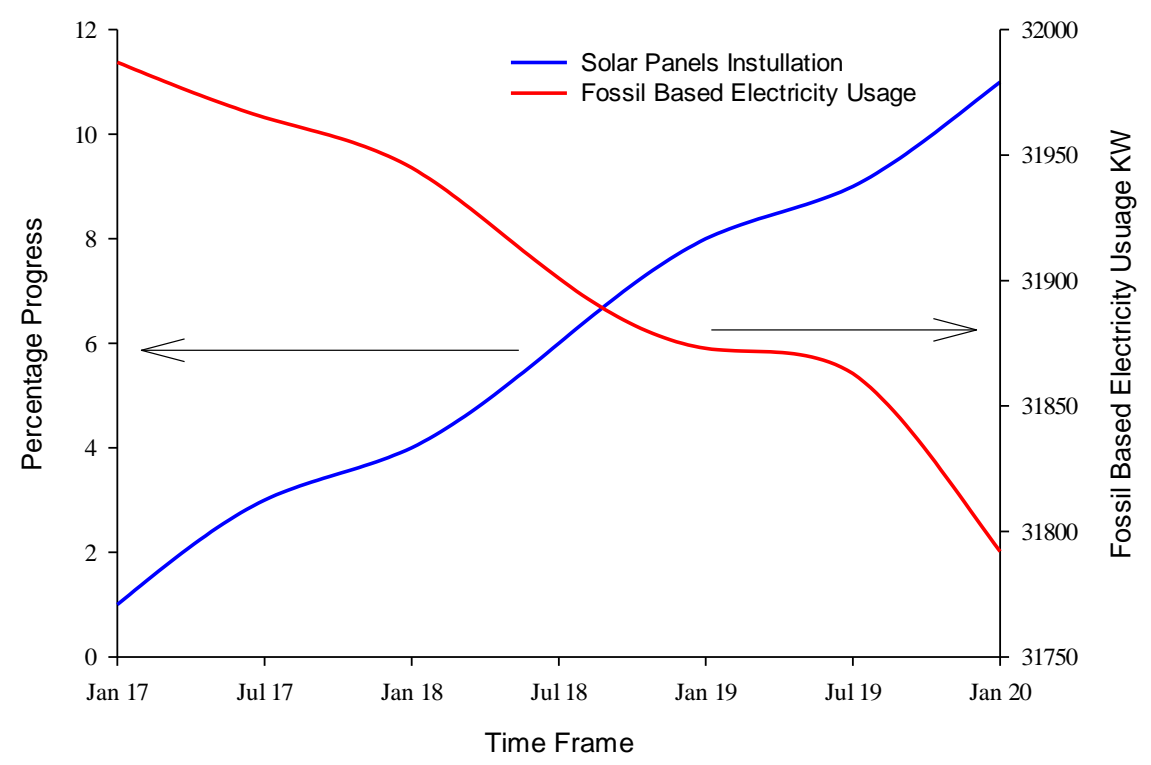

Figure 2. The progress of solar panel installations versus overall fossil-based electricity usage in all ATU sites

\section{Waste and Water Management}

In the recent past, ATU was encountering what is commonly known as wastewater emissions. This is since daily considerable amount of freshwater is consumed for operating one site, mainly due to both municipal sources and laboratories activities. Indeed, having multiple sites separated on a huge region like ATU case, makes it very costly to establish incampus wastewater treatment plants. In this respect, ATU has relied on local governmental wastewater treatment plants to pre-treat its sites' wastewater before mixing it with municipal wastewater.

However, and in order to increase the overall freshwater efficiency, wastewater minimization approach was employed at ATU such as source reduction. Source reduction attempts to reduce the total water consumption. For ATU, a large water-saving training program was proposed and implemented so as to transfer water saving knowledge and practices to all the faculties and students. Pamphlets and outdoor bulletin boards that contain best practices on water saving were prepared and released across the whole campus. Practically, ATU shifted to use water from water wells as they are steadily available 
in almost all sites areas. Nowadays, all extracted water is employed in many purposes including flushing free urinals and toilets, watering the gardens and general irrigations and cleaning activities. With such an effort, many water saving opportunities were identified and implemented by the university societies, such as finding and drill water wells and applying water-saving taps in all sites.

\section{Education}

Moving towards green universities goals and arising national environmental issues have driven ATU to establish two research laboratories focusing on environmental protection in two separated sites namely, Kufa and Al-Musayyib. Such labs are mainly funded by the Ministry of Higher Education and Scientific Research through ATU university along with many competitive research grants from the Ministry of Environment, Ministry of Science \& Technology and local governments. Such grants provided a lot of opportunities to renovate ATU's research facilities and enhanced their research ability. By undertaking such effort, both ATU faculties and students can learn from the real world and improve their ability through problem solving. It can also improve the collaboration with the local government and create job opportunities for ATU students.

One of the ATU university sustainable goals is to create futuristic engineers, managers and leaders who are integrated with appropriate knowledge and skills of environmental protection so they can avoid or minimize material consumption and waste emissions in their work fields. Furthermore, ATU is confident that manifold possibilities to put sustainability into practice could be offered to students, staff and faculties thereby implementing green education. In addition to ATU education efforts on energy saving, water saving and solid waste management, an environmental protection course is offered for all students, staff and faculties nowadays by ATU university. Fundamentals of environmental science, energy conservation, water resources management and waste management topics are fully covered through thiscourse. The course is periodically available for anyone which offers a great opportunity for all to learn from, share knowledge with, and gain respect for each other so that they can overcome their biases and misconceptions about other fields.

\section{Conclusion}

With rapid industrialization and an increasing environmental crisis, have urged the successful implementation of green university efforts by Al-Furat Al-Awsat Technical University ATU. The previously ATU approved sustainable development scheme has proved to pose multiple benefits including reduced energy costs, reduced wastes, or better waste managements, reduced total emissions, enhanced public awareness and improved public image. Some development projects were found to smoothly grown, while others are yet straggling to complete. This study concluded the fact that the strong governmental involvement would play an important role in accelerating many sustainable development projects towards the completion. Since green university efforts requires remarkable funds to initiate different projects, such as equipment purchasing, plants establishing, training and promotion. Indeed, it seems so hard for ATU to apply specific subsidies from its annual budget or governmental funds, since the last is mainly consumed by academic activities. Leaving such green university scheme relying on received budgets from other governmental agencies and or its own teaching and research incomes. Despite the challenges due to shortage governmental funds, ATU is keen to make remarkable efforts towards the completion of all sustainable environmental goals. 


\section{References}

1. Disterheft, A., et al., Environmental Management Systems (EMS) implementation processes and practices in European higher education institutions - Top-down versus participatory approaches. Journal of Cleaner Production, 2012. 31: p. 80-90.

2. Sammalisto, K. and T. Brorson, Training and communication in the implementation of environmental management systems (ISO 14001): a case study at the University of Gävle, Sweden. Journal of Cleaner Production, 2008. 16(3): p. 299-309.

3. Espinosa, R.M., et al., Integral urban solid waste management program in a Mexican university. Waste Management, 2008. 28: p. S27-S32.

4. Mason, I.G., et al., Implementation of a zero waste program at a university campus. Resources, Conservation and Recycling, 2003. 38(4): p. 257-269.

5. Mason, I.G., A. Oberender, and A.K. Brooking, Source separation and potential re-use of resource residuals at a university campus. Resources, Conservation and Recycling, 2004. 40(2): p. 155-172.

6. H. Larsen, H.N., et al., Investigating the Carbon Footprint of a University - The case of NTNU. Journalof Cleaner Production, 2013. 48: p. 39-47.

7. Wang, M., Wei, D.Y., He, Y.Q.,, A review of China's green university construction and practices. Environmental Protection, 2010. 19: p. 44-47.

8. Wang, L., Review on the research of connotation and evaluation index system of green university in China. Journal of Jinling Institute of Technology (Social Science), 2011. 25(4): p. 5-9.

9. Shi, J.J., Creating low carbon campus by applying the concept of green university. China Higher Education, 2010. 12: p. 12-22.

10.Morin, E., Seven complex lessons in education for the future, UNESCO, Paris, unesco.org/images/0011/001177/117740eo.pdf. 1999.

11.UNESCO, Education for Sustainable Development Goals: Learning objectives, unesdoc.unesco.org/images/0024/002474/247444e.pdf. 2017, UNESCO: Paris. 